\title{
New Disease Reports \\ First report of bleeding canker caused by Rahnella sp. on Populus nigra in Iran
}

Y. Moradi-Amirabad and G. Khodakaramian*

Department of Plant Protection, Faculty of Agriculture, Bu-Ali Sina University, Hamadan, Iran

*E-mail: Khodakaramian@yahoo.com

Received: 26 Feb 2020. Published: 27 Jun 2020. Keywords: bacterial bark canker, bleeding stem, poplar

In 2019, a bleeding canker with a sour-smelling and brownish liquid exudate was observed on mature (>10 years old) black poplar (Populus nigra) trees in eight poplar plantations in the Hamadan, Kermanshah, Isfahan, and Kohgiluyeh and Boyer-Ahmad provinces of Iran. Up to 85\% of trees were affected in some stands and the trees showed a general decline and yellowing of leaves. The exudates and cankers were found on the trunk in spring and summer (Fig. 1). The symptoms were similar to bark canker of Populus $\times$ euramericana in Spain (Biosca et al., 2006).

Samples were collected from symptomatic trees. Fifteen isolations of bacteria were made on nutrient agar (NA; Merck, Germany) from the interface between diseased and healthy tissue based on Moradi-Amirabad $e t$ al. (2019). In all cases the predominant bacteria were cream, round, convex and smooth with entire margins on NA. Phenotypic tests were performed based on standard methods (Schaad et al., 2001). All isolates were Gramnegative, and facultatively anaerobic, positive for catalase, nitrate reduction, and hypersensitive reaction on geranium (Pelargonium $\times$ hortorum), but negative for oxidase, arginine dihydrolase, urease, lysine and ornithine decarboxylase, hydrogen sulphide and indole production, citrate utilization, and fluorescent pigment production on King's medium B. All isolates produced acid from D-fructose, D-galactose, D-glucose, D-lactose, D-maltose, D-mannitol, D-mannose, D-melibiose, Dribose, D-sorbitol, D-trehalose, D-xylose, L-arabinose, and salicin. The isolates were phenotypically identical to members of the Yersiniaceae, specifically Rahnella spp. (Brady et al., 2014).

DNA was extracted from a representative isolate (P1) (Moradi-Amirabad $e t$ $a l ., 2019)$. House-keeping genes $g y r B$ and inf $B$ were partially sequenced (Brady et al., 2008) (Genbank Accession Nos. MT107177 and MT107178) and had 100 and $99.67 \%$ identity with Rahnella sp. strain L31-1-12, respectively. Using a neighbour-joining clustering algorithm based on the concatenated $\operatorname{gyr} B$, and infB sequences, the $\mathrm{P} 1$ isolate clustered with Rahnella sp. strain L31-1-12 on a separate branch from other Rahnella spp. (Fig. 2). This suggests that the isolates from poplar trees in Iran belong to the genus Rahnella but are distinct from other named species.

Pathogenicity tests were performed as described by Li et al. (2014). Four strains (P1, P3, P7, and P12) were cultured on NA for $48 \mathrm{hr}$ at $28^{\circ} \mathrm{C}$. Bacteria were suspended in sterile distilled water (c. $10^{7} \mathrm{CFU} / \mathrm{ml}$ ) and 100 $\mu \mathrm{l}$ was pipetted into cross-shaped wounds ( $5 \mathrm{~mm}$ long) made in the bark of three excised stems with a sterile knife. Control stems were inoculated with sterile distilled water. Inoculated stems were enclosed with polyethylene bags and kept in darkness at $28^{\circ} \mathrm{C}$. Canker symptoms with copious brownish exudate appeared seven days after inoculation (Fig. 3). The inoculated isolates were re-isolated and their identity confirmed based on phenotypic characteristics. Control stems did not produce any symptoms and no bacteria were isolated from them.
Rahnella spp. have been associated with acute oak decline symptoms (e.g. bleeding stem) on oak and hornbeam (Brady et al., 2014; Moradi-Amirabad et al., 2019). This is the first report of a Rahnella sp. causing a bleeding canker on poplar trees in Iran and worldwide.

\section{Acknowledgements}

The authors would like to thank the research deputy of Bu-Ali Sina University, Hamadan, Iran for financial support, and Ms. Shima Bagherabadi, and Mr. Syamak Hanifeh from our laboratory for their help during the sampling.

\section{References}

1. Biosca EG, Martín S, Zuriaga P, Montón C, López-Ocaña L, López MM, 2006. Characterization of Brenneria sp. from poplar cankers in Spain. In: Mendez-Vilas A, ed. Modern Multidisciplinary Applied Microbiology: Exploiting Microbes and Their Interactions. Weinheim, Germany: Wiley, 385-389. http://dx.doi.org/10.1002/9783527611904.ch68

2. Brady C, Cleenwerck I, Venter S, Vancanneyt M, Swings J, Coutinho T, 2008. Phylogeny and identification of Pantoea species associated with plants, humans and the natural environment based on multilocus sequence analysis (MLSA). Systematic and Applied Microbiology 31, 447-460. http://dx.doi.org/10.1016/j.syapm.2008.09.004

3. Brady C, Hunter G, Kirk S, Arnold D, Denman S, 2014. Rahnella victoriana sp. nov., Rahnella bruchi sp. nov., Rahnella woolbedingensis sp. nov., classification of Rahnella genomospecies 2 and 3 as Rahnella variigena sp. nov. and Rahnella inusitata sp. nov., respectively and emended description of the genus Rahnella. Systematic and Applied Microbiology 37, 545-552. http://dx.doi.org/10.1016/j.syapm.2014.09.001

4. Li Y, He W, Ren F, Guo L, Chang J, Cleenwerck I, Ma Y, Wang H, 2014. A canker disease of Populus $\times$ euramericana in China caused by Lonsdalea quercina subsp. populi. Plant Disease 98, 368-378. http://dx.doi.org/10.1094/PDIS-01-13-0115-RE

5. Moradi-Amirabad Y, Rahimian H, Babaeizad V, Denman S, 2019. Brenneria spp. and Rahnella victoriana associated with acute oak decline symptoms on oak and hornbeam in Iran. Forest Pathology 49, 1-14. http://dx.doi.org/10.1111/efp.12535

6. Schaad NW, Jones JB, Chun W, eds, 2001. Laboratory Guide for Identification of Plant Pathogenic Bacteria. Saint Paul, USA: APS Press.

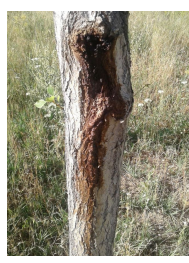

Figure 1

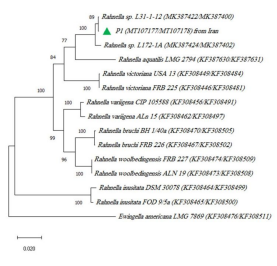

Figure 2

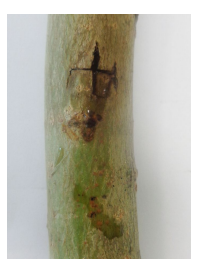

Figure 3

To cite this report: Moradi-Amirabad Y, Khodakaramian G, 2020. First report of bleeding canker caused by Rahnella sp. on Populus nigra in Iran. New Disease Reports 41, 37. http://dx.doi.org/10.5197/j.2044-0588.2020.041.037

(c) 2020 The Authors

This report was published on-line at www.ndrs.org.uk where high quality versions of the figures can be found. 